\title{
The Limited Partner Position in bankruptcy Limited Partnership (CV) in Indonesia
}

\author{
Siti Mahmudah, Siti Malikhatun Badriyah, Kashadi \\ \{Sitimahmudah.fhundip@gmail.com ${ }^{1}$, sitimalikhatun@live.undip.ac.id ${ }^{2}$ \} \\ ${ }^{1,2,3}$ Faculty of Law, University of Diponegoro
}

\begin{abstract}
Limited Partnership or CV is a form of company which is used in the running of the company. There are two types of partner in the Limited Partnership that is complementary partner or managing partner and limited partner. Article 1 (11) Act No. 37 Th 2004 about Bankruptcy and PKPU (UUK-PKPU) set about the debtor that can be requested to be declared bankrupt, one of them was the Limited Partnership. Related to the bankruptcy of Limited Partnership, interesting to review more about the Limited partner. Can Limited partner responsible for inbrenk be requested to be declared bankrupt against the Limited Partnership debt that is settlement bankruptcy? Statements in bankruptcy can only be addressed to the debtor who has at least two creditors and do not pay in full at least one loan that already fall time and billable (article 2 paragraph UUKPKPU). In Indonesia Limited Partnership not a legal entity so that it's not legal subjects as Limited liability company. UUK-PKPU does not regulate who can be petitioned to be declared bankruptcy Limited Partnership. According to article 19 KUHD managing partner are responsible for debt limited partnership. According to article 21 KUHD limited partner are also responsible as managing partner if they carry out management or work in the limited parnership. Limited Partner can thus serves as the debtor that can be petitioned to be declared bankrupt in bankruptcy Limited Partnershipi if it complies with the provisions of article 21 KUHD and article 2 paragraph 1 UUK-PKPU.
\end{abstract}

Keywords: Limited Partner Position, bankruptcy Limited Partnership

\section{Background}

We find various forms of cooperation in the community in fulfilling life needs. Various forms of cooperation can be distinguished in cooperation that is social or purposeful and cooperation that is economic or objective. The purpose of economic cooperation is to make a profit. This advantage is realized by running a company, which is one of the elements that must exist in running the company as stated by Polak, and Molengraf. The elements of running the company, including continuous elements openly, in certain positions aim to obtain profits and be recorded in accounting.

Based on the number of owners, the form of the company can be distinguished in a company owned by one person and owned by several people. A company owned by several people is a partnership called a partnership which is distinguished in a partnership in the form of a legal entity and a non-legal entity. Forms of fellowship that are not legal entities, based on their 
differentiated arrangements, are regulated in the Civil Code (BW / KUHPerdata) namely the Civil Society Association, and which are regulated in the Commercial Law Act (WvK /KUHD), which includes Fellowship with the Firm (Fa.) And Limited Partnership (CV) [1].

$\mathrm{CV}$ (Commanditaire Vennootschap or Limited Partnership) is one form of company that is widely used by the community in running the company, which can be seen in the data from the 2015 Central Java Large Medium Manufacturing Industry Directory, as table 1.

Tabel 1. Data Company from 2105

\begin{tabular}{ll}
\hline Company Form & Total \\
\hline PT & 189 \\
UD & 8 \\
CV & 44 \\
Other forms & 65 \\
Total number & 306 \\
\hline
\end{tabular}

Profits which are the objectives in running the company are obtained by carrying out legal actions in the legal field of engagement originating from the agreement. In the Communion Committee or CV the legal action is carried out by the management Partner, also called complementary Partner, as stipulated in Article 19 KUHD.

The Limited Partnership have two types of partner, namely complementary partner as partner of management or active partner and commanders who are referred to as money-releasing partners or passive partner. The complementary partner are jointly responsible for the fellowship of the partner while the comanditer partner or limited partner are responsible only as far as the debt.

In running this company there is a possibility that the Limited Partnership or CV cannot fulfill its obligations, which results in the CV being positioned as a Debtor or a party that has debt. Debt is an obligation whose fulfillment is guaranteed in Article $1131 \mathrm{BW}$, which can be done outside or through a court

Debtor settlement through court can be settled through bankruptcy, as stipulated in Law No. 37 of 2004 concerning Bankruptcy and PKPU, hereinafter referred to as UUK-PKPU. According to Article 1 points 11 and 2 (1) UUK-PKPU, the Limited Partnership or CV is a form of non-legal entity company that can be applied for bankruptcy.

Problem

Debtors who have at least two creditors and one of their debts is due and can be billed can be requested to be declared bankrupt through a bankruptcy statement request that can be made by the debtor or one of its creditors (Article 2 (1) UUK-PKPU). The bankruptcy statement resulted in the existence of a general seizure of the assets of the bankrupt debtor.

Considering that the Limited Partnership or CV is one of the non-legal entities that has two types of Partner that have different responsibilities for partnership debt that can be applied for bankruptcy, it is interesting to examine how the position of the responsible limited partner in fact was caused by the bankcruptcy of the Limited Partnership, can a Limited Partner's personal assets be used as collateral for repayment of CV debt declared bankrupt? 


\section{Methods}

This research outline can be grouped in the doctrinal legal research which researches on the law that is originated and developed on the basis of the doctrine that embraced by the conceptual and or the developer. This research using the methods of the study of the law which conceptualized as a rule of law according to the doctrine of the positivism flow in the science of law often referred to as a research method that normative [2]. The normative legal research is a type of research that is often done in the activities of the development of the science of the law in the west usually also called dogmatics law (Rechtdogmatiek)[3]. Thus the approach method used in this research is the normative juridical approach because this research wants to find the law for an inconcreto case which is an effort to find the appropriate law to be applied inconcreto to resolve a certain case and where the sound of the regulation found[4].

The specifications in this research is a descriptive analytical. This means that a descriptive paints the research object based on the fact that there is, conducted systematically, chronological order based on the rules of the scientific. Analytical means describes the research object associated with the theories of existing law and/or legislation related to the object that is examined. This research is intended to find out about The Limited Partner Position in bankruptcy Limited Partnership (CV) in Indonesia, which then continued to analyze it from the aspect of the law by using the rules of applicable law.

The type of data in this research is secondary data, in the form of legal materials. The material of the law is the source of the data that is required in the implementation of a research. Legal materials include primary legal materials, secondary legal material and tertiary legal materials. In this research it uses the primary legal materials and secondary legal materials. Secondary legal materials data is strengthened by the results of the interview that is more inventarized, which began with the identifying and followed by the election of the legal materials in a systematic and logical way, then analyzed in qualitative research using logic deductive and assisted with the approach of legislation, so that it can be explained about The Limited Partner Position in bankruptcy Limited Partnership (CV) in Indonesia.

\section{Material and Discussion}

Basically the Limited Partnership (CV) is a collaboration in meeting the needs of human life. This can be seen from the history of the birth of the Commander Association. The Limited Partnership is a development of a form of partnership [5] that has been known before. Along with the development of the merchant community and trade which are increasingly spreading to various regions, merchants need a form of business that can unite capital and entrepreneurs who dare to take risks by shipping. The general partnership form is considered not able to meet this need. As a result the Mercantile System recognizes another form of partnership, namely Commenda [5].

Commenda is the initial form of a communal partnership. Commenda is a voluntary agreement, but cannot function perfectly if it is not supported by a community that understands the law. Therefore a legal system is needed that confirms the rules that define and apply behavior in general, and develop more detailed rules [5]. 
In France the Limited Partnership were first recognized in the Act in 1673 and regulated in the Commercial Code in 1807. In 1809 the Netherlands as a French colony imposed the de Napoleon code which contained the code de civil and code de commerce then, in 1838 the Dutch coded the BW and WvK, which largely imitated French codification. BW comes from de civil code and WvK from code de commerce. When the Dutch colonial period, BW and WvK were implemented by the Dutch East Indies Government based on the concordance principle contained in Article 131 IS in the Dutch East Indies, which subsequently BW was translated by the Book Civil Law (KUH.Perdata), while WvK is translated into Commercial Law (KUH.Dagang) [5].

KUH. Civil Code and Criminal Procedure Code, until now still valid, although there are several provisions that are not valid because they have been specifically regulated in a statutory regulation. KUH. Data and KUHD are sources of law in the business world. The relationship between the Civil Code and KUHD can be seen in the provisions of Article 1 and 15 KUHD. Based on these two articles, the provisions in the KUH. Dirat and KUHD are the source of law in the Limited Partnership.

Article 15 of the Criminal Procedure Code stipulates that all the companies in this chapter are controlled by the parties concerned, by this book and by civil law. Thus the agreement on the establishment of a command partnership is subject to the treaty law stipulated in book III KUH. Book III KUH. The regulators regulate the engagement which one of the sources is the agreement as stipulated in Chapter II which regulates the engagement - the agreement that is born of the contract or agreement.

Commander association is basically a collaboration, the agreement in the cooperation is set forth in an agreement that is subject to the treaty law stipulated in book III KUH. Thus the legal relationship of the Partner in the $\mathrm{CV}$ is based on the agreement, as well as the legal relationship between $\mathrm{CV}$ as a form of cooperation in running the company with the community which can result in the bankruptcy of the $\mathrm{CV}$ also based on the agreement.

According to Article $1313 \mathrm{KUH}$. Registration of agreements is an act in which one person or more ties himself to one or more other people ". Agreements made legally apply as laws for the parties making them (provisions of Article). The agreement is valid, if it fulfills four (4) conditions which are regulated in Article 1320, which are agreed, capable, certain matters and legal reasons.

Based on the provisions of the articles above, in the agreement there must always be two parties as the subject of the agreement, namely the debtor and the creditor. The agreement creates rights and obligations for the parties. If the agreement is made legally then the agreement applies as a law for the parties that make it (the principle of the power of binding an agreement or Pacta Sunt Servanda). Thus those who are entitled to fulfillment of achievements (creditors) can demand the fulfillment of achievements to parties who are obliged to fulfill their achievements (debtors).

Fulfillment of these achievements is guaranteed by the debtor's assets both existing and future, as stipulated in Article $1131 \mathrm{KUH}$. Civil Code, which is all the material of the debtor (debtor), both movable and immovable or immovable, both existing and new, will become a guarantee of all the personal obligations of the debtor ". The provisions of Article 1131 contain the principle that everyone is responsible for the debt we call the pari passu pro rata parte principle. The responsibility is in the form of providing his property both movable and immovable objects for repayment of his debts, and if the number of creditors is more than one, 
the provisions of Article 1132 stipulate that the Material in Article 1131 is a joint guarantee for the creditors, and the auction results of the material divided among the balanced managers according to the size of their respective receivables, except for legitimate reasons to prioritize one receivable from the other receivables ". The provisions of Article 1132 contain the principle of creditorium parity.

From the two Articles, it can be seen that the law has regulated the assets of debtors who are called debtors to guarantee their debts or in other words creditors' receivables are guaranteed by debtor's assets if the debtor does not fulfill their obligations [6].

According to Sutan Remy Sjahdeini, only by setting the priority level and repayment sequence of each creditor's receivables by law as stated in the KUH. The registry is not enough, because in addition to the provisions concerning priority level and order of repayment of each receivable as stipulated in $\mathrm{BW}$, another law is also needed to regulate how to divide the proceeds of the sale of debtor's assets to pay off the credit of each creditor based on the order of priority levels. In addition, it must also be determined by other laws by who the division is done, and how to do it. The law in question is the Bankruptcy Act. At present the bankruptcy law that applies in Indonesia is Law No. 37 of 2004. L.N.R.I. Year 2004 No.131 [7].

In practice not always the debtor can fulfill his obligations. Bankruptcy institutions are institutions that can be used to settle debtor obligations that have not been fulfilled. According to the provisions of Article 1 point 1 of Law No. 37 of 2004 concerning Bankruptcy and Postponement of Payment Obligations, hereinafter referred to as UUK-PKPU, what is meant by bankruptcy is the general seizure of all the assets of bankrupt debtors whose control and delivery is carried out by the curator under the supervision of the supervisory judge as stipulated in this Act. The supervisors and judges were appointed together with the statement of the debtor's bankruptcy decision.

General confiscation is a seizure carried out on all property owned by the debtor both existing and future in order that the proceeds from the confiscated assets can be distributed fairly and proportionally among fellow creditors in accordance with the amount of receivables from each except among creditors there is a reason to take precedence [8]. According to Hadi M. Shubhan, general seizures have differences from other civil lawsuits, namely general seizures do not require a specific action or certain legal actions such as other confiscations in civil law [9].

Thus the certainty of the debtor who can be declared bankrupt is very important, because this debtor's assets will be confiscated which will then be distributed to the creditors as stipulated in the provisions of Articles 1131 and 1132 KUH. Civil.

According to Article 1 number 11 the debtor is a person who has a debt due to an agreement or law whose repayment can be billed before the court, while what is meant by people according to Article 1 point 11 are individuals or corporations including corporations in the form of legal entities or non-legal entities in liquidation. While creditors are people who have receivables because of agreements or laws that can be billed before the court.

According to the provisions of Article 2 (1) UUK-PKPU, the debtor that can be applied for bankruptcy is a debtor who has at least two creditors and one of his debts has matured and can be billed.

Thus CV is a debtor that can be applied for bankruptcy. An application for a CV bankruptcy statement can be made by $\mathrm{CV}$ as a debtor or one of his creditors. $\mathrm{CV}$ is a business entity that is not a legal entity. Business entities are business organizations that are established by more than one individual carrying out business objectives, namely profitability, while elements of legal 
entities are the existence of separate assets; have a specific purpose; have interests and have a regular organization. Therefore if the $\mathrm{CV}$ has a debt, then the person responsible for paying the debt is not limited to the property of CV.

The Limited Partner is one form of non-legal entity company regulated in the KUHD. There are three articles governing the CV in the KUHD, namely Article 19 through Article 21 KUHD. Three of these articles are in the second part of the Company Firms and Companies that release money, which are also referred to as Limited Partnership. Based on these three articles, there are two types of Partner in the CV, namely limited Partner and complementary Partner. The limited partner are also called money-releasing Partner, namely Partner who may not carry out management actions or work in an alliance even though there is power, which is limited to the company's loss, which is limited to money that has or must be included (Article 20 paragraph 2) unless he violates the provisions of Article 20 (2) and does not have to return the profits he has enjoyed (Article 20 paragraph 3), while complementary Partner are Partner of the management who are entirely responsible for all partnership agreements with the moneyreleasing party.

Thus according to the provisions of Article 19 to $21 \mathrm{KUHD}, \mathrm{CV}$ has two Partner who have different responsibilities for debt CV. The complementary Partner are unlimited Partner of the responsible management. If the $\mathrm{CV}$ has a debt, the personal assets of the complementary Partner that become collateral for repayment of the debt of CV. Allied Komanditers are money-letting Partner or passive Partner. Komanditer Partner are not Partner of management. Commandant Partner do not carry out management actions as complementary Partner. The limited partner have limited responsibility, which is limited to capital or inbrenk which must be included in the Limited Partner. The responsibility of a partner ally becomes unlimited if he participates in the arrangement (provision of article 20 KUHD).

According to Sukardono, the responsibility of the military Partner is only about debts that are running and which will arise as long as the condition of the violation is still ongoing [10].

The bankruptcy statement resulted in the existence of a general seizure of the assets of the bankrupt debtor. General seizure is the confiscation of property with absolute ownership of the debtor, both present and in the future which is used as collateral for debtor receivables to the creditors. The existence of this general confiscation has resulted in the debtor losing the right to manage and settle his assets.

Given that $\mathrm{CV}$ is a non-legal entity business entity, which has two Partner and according to the provisions of Articles 19 to 21 of the KUHD, the two types of Partner can be responsible up to their personal assets. In other words, the $\mathrm{CV}$ debt that must be paid is the payment guaranteed by the assets of complementary Partner and partners. Thus if the CV has creditors, the repayment of the creditor's debt is guaranteed by the assets of its Partner.

In the practice of choosing the form of CV in running the company a lot is done so too if the $\mathrm{CV}$ has a debt settlement debt through bankruptcy also occurs in the CV. In the settlement of bankruptcy, CV can act as the applicant for both $\mathrm{CV}$.

both the petitioners and the petitioners can be seen in the bankruptcy case filed in the Commercial Court from 2015 to 2018 . Within this period there were $17 \mathrm{CVs}$ as applicants and $21 \mathrm{CV}$ s as defendants.

Debtor certainty that can be applied for bankruptcy is very important for creditors because the repayment of creditors' receivables is guaranteed by bankrupt or boedel bankrupt assets from bankrupt debtors, as a realization of the provisions of Article $1131 \mathrm{BW}$ 
According to the provisions of Article 19 to Article $21 \mathrm{WvK}, \mathrm{CV}$ receivables are guaranteed by Partner. Thus the CV Partner are debtors for $\mathrm{CV}$ debts to their creditors. If the $\mathrm{CV}$ debt settlement is carried out by using a bankruptcy institution, the CV Partner are debtors who can be applied to be declared bankrupt if they fulfill the requirements as stipulated in the provisions of Article (1) UUK-PKPU.

Regarding the requirements for bankruptcy statements against CV Partner, there is a difference between complementary Partner and partner Partner. The provisions of the alliance are valid (Article 19 KUHD) Complementary Partner are personally responsible for the entire $\mathrm{CV}$ engagement, because only complementary Partner can establish legal relations with third parties. While the allied commanders only roast the answer for the amount of income (provision of article 19 KUHD). A partner ally will be personally responsible for the whole if he or she participates in the arrangement (provision of article $20 \mathrm{KUHD}$ ).

\section{Conclusion}

Allied commanders are responsible not limited to capital or capital which is a necessity to become a partner ally at the command partnership if it meets the provisions of the Article ,,,,, KUHD. The private assets of the conventional Partner become collateral for the debt of the partnership partnership if they fulfill the provisions of Article ..... KUHD. Allied Commanditers' assets can be used as collateral for repayment of CV pliers which are stated as fulfilling the provisions of Article ... KUHD. Partner of the Commanders can be declared bankrupt in relation to the bankruptcy of the $\mathrm{CV}$ as long as they fulfill the provisions of Article ... KUHD and Article 2 (1) UUK-PKPU

\section{References}

[1] K. G. Jöreskog and D. Sörbom, 'Model search with TETRAD II and LISREL', Bur. as Externalized Self-System, vol. 19, no. 1, pp. 93-106, 1990.

[2] S. Wignjosoebroto, Hukum: Paradigma, Metode dan Dinamika Masalahnya. Jakarta: Elsam \& Huma, 2003.

[3] B. A. Sidharta, 'Penelitian Hukum Normatif: Analisis Penelitian Filosofi dan Dogmatikal', in Metode Penelitian Hukum, Konstelasi dan Refleksi, S. Irianto and B. A. Sidharta, Eds. Jakarta: Yayasan Obor Indonesia, 2009.

[4] R. H. Soemitro, Metodologi Peneleitian Hukum dan Juri Metri. Jakarta: Ghalia Indonesia, 190AD.

[5] Y. K. D. K. Dewi, New Thought About Commanditaire Vennootschap (CV). FH Universitas Indonesia Publ. Inc, 2011.

[6] S. Mahmudah, 'Juridical Review of the Responsibilities of Directors in Bankruptcy of Limited Liability Companies According to Law No. 40 of 2007', Leg. Issues, vol. 41, no. 3, pp. 427-477, 2012.

[7] Sutan Remy Sjahdeini, Bankruptcy Law Understanding Law No.37 of 2004 concerning Bankruptcy. Jakarta: Pustaka Utama Grafiti, 2010. 
[8] S. H. Isfardiyana, 'General Sita Bankruptcy precedes Criminal Confiscation in Bankruptcy Settlement', Padjadjaran J. Ilmu Huk., vol. 3, no. 3, 2016.

[9] L. F. Nola, 'The Public Seizure Position against Other Sita in the Bankruptcy Process The Position of General Security Towards Others in the Process of Bankrupcy', Indones. Sci. J. State Law Build. Law Justice Welf., vol. 9, no. 2, 2018.

[10] Soekardono, Indonesian Commercial Law Volume I. Bandung, 1987. 